\title{
Elemental Composition and Morphological Characteristics of Kidney under the Influence of Toxicants
}

\author{
Elena V. Kiyaeva ${ }^{1}$, Svetlana V. Notova ${ }^{1,3}$, Inara E. Alidzhanova ${ }^{1}$, Ludmila L. Abramova ${ }^{2}$ \& Galimzhan K. \\ Duskaev $^{3}$ \\ ${ }^{1}$ Orenburg State University, Orenburg, Russia \\ ${ }^{2}$ Orenburg State Agrarian Universities, Orenburg, Russia \\ ${ }^{3}$ All-Russian Research Institute of Beef Cattle Breeding, Orenburg, Russia \\ Correspondence: Elena V. Kiyaeva, Orenburg State University, Orenburg 460018, Russia. Tel: 7-890-3362-6182, \\ E-mail: elena_sap@mail.ru
}

Received: July 1, 2015

doi:10.5539/mas.v9n10p1
Accepted: July 11, 2015

Online Published: August 30, 2015

URL: http://dx.doi.org/10.5539/mas.v9n10p1

\begin{abstract}
Morphological changes and element status in laboratory animals under the influence of ethanol and cadmium were studied. Male Wistar rats were under investigation. Experimental animals received standard diet and in addition $15 \%$ ethanol solution and cadmium sulfate orally. Histologic and morphometric studies were done. Routine Mayer's hematoxylin and eosin stain for renal histological sections was used. Ocular micrometer MOB-1-15x1500 and software "Test Morpho 4.0" were used for investigation of histological and cytological structures of kidneys. Digital images were produced by microscope "Micros" (Austria).

The methods of inductively coupled plasma spectroscopy and atomic emission spectroscopy (Optima $2000 \mathrm{DV}$ and ELAN 9000, PerkinElmer, USA) were used for the elemental study of samples.

The combined effect of ethanol and cadmium sulfate caused renal damage which was confirmed morphologically. It was found that $65 \%$ nephrons were exposed to destruction with microinfarctions. Volume of $80 \%$ renal corpuscles was reduced, but volume of nephrocytes was extended at all levels of nephron. Cavities of the renal tubule were extended in the area of Henle's loop. In addition to kidney damage the concentrations of $\mathrm{Mg}, \mathrm{P}, \mathrm{As}$, $\mathrm{Fe}, \mathrm{Cu}, \mathrm{Si}, \mathrm{Zn}$ were decreased and $\mathrm{Cd}$ concentration was increased in the blood of laboratory animals, who were exposed to ethanol and cadmium. The concentration of cadmium was 86 times $(p \leq 0,001)$ higher and the concentration of lead was 25 times $(\mathrm{p} \leq 0.05)$ higher in the hair of animals from the experimental group than in the hair of animals from the control group.
\end{abstract}

Keywords: kidney, ethanol, cadmium, trace elements

\section{Introduction}

Presently the research of influence of different factors on element homeostasis and morpho-functional state in human and animals is especially topical. Due to consumption of alcohol and tobacco, which accumulates cadmium (Ergen, K. et al., 2012), the simultaneous effect of ethanol and cadmium on organism occurs frequently (Falcon, Vinas, Perez-Carceles, \& Luna, 2003; Malov, A.M., Sibiryakov, V.C. \& Ivanenko, A.A., 2013). In addition, the increasing production and usage of cadmium compounds lead to a sufficient enhancement of cadmium concentration in the environment (Ikeda et al., 2000; Aghajanian \& Skalny, 2001; Lyon et al., 2002; Onishchenko, 2003; Stepanova, 2003 ). Alcohol has complex toxic effects on the human organism (Gerke, P., Hapke, U., Rumpf, H. J., \& John, U., 1997; McIntosh, C., \& Chick, J.,2004). Cadmium metabolism and toxicity can change under the influence of different factors. (Brzoska, Moniuszko-Jakoniuk, Piłat-Marcinkiewicz, \& Sawicki, 2003).

The purpose of the research is investigation of influence of ethanol and cadmium on the laboratory animals' renal tissue and element status.

\section{Materials and Methods}

\subsection{Animals}

The experimental model of simultaneous influence of ethanol and cadmium was created. The investigation was 
performed with the usage of male Wistar rats $(\mathrm{n}=20$, weight $=180 \pm 10.2 \mathrm{~g})$. The animals were kept in clinical and biological laboratory "Vivarium" (Orenburg State University). They were maintained in controlled environment $(12: 12 \mathrm{~h} \mathrm{light} / \mathrm{dark}$

cycle).The experiment was conducted by observing humane principles as presented by European Community Directive 86/609/EC.

\subsection{Treatment Design}

The duration of the experiment was equal to 45 days. Experimental animals received nutritionally balanced diet and extra $15 \%$ (w/v) ethanol solution $(42.3-48.9 \mathrm{~g} / \mathrm{kg} / \mathrm{day})$, cadmium sulfate $23.55 \mathrm{mg} / \mathrm{kg} / \mathrm{day}$ was added to food (the dose was selected according to (Izmerov, 1984), the rats were allowed free access to food anad water. In average the rat received $3.2-3.4 \mathrm{mg}$ cadmium sulfate $/ \mathrm{kg}$ body weight per day. The animals of control group received standard diet and tap water ad libitum. At the end of experimental period anesthetized rats were decapitated.

\subsection{Trace Element Analysis}

25 chemical elements were detected in the samples of the rat blood and hair. Analysis were performed in laboratory "Center for Biotic Medicine" (registration number state register RU 0001. 513118; May 29 2003; Registration Certificate of ISO 9001: 2000, Number 4017-5.04.06) using the methods of inductively coupled plasma spectroscopy and atomic emission spectroscopy (ICP-AES Optima 2000 DV and ELAN 9000 (Perkin Elmer, USA)).

\subsection{Histological Analysis}

The extraction of histological material from different renal parts was performed during the 30 minutes interval after animals' death. The material was fixed in a $10 \%$ neutral buffered formalin, then passed through a battery of alcohols with growing strengths and then covered in paraffin. Routine Mayer's hematoxylin and eosin stain for renal histological sections (thickness - 5-6 mkm) was used. Ocular micrometer MOB-1-15x1500 and software “Test Morpho 4.0"(Russia) were used for investigation of kidney histological and cytological structures, parameters of cell structure and cell nucleus. Each sample of tissue was studied at least from 16 views. Digital images were produced by the microscope "Micros" (Austria). The interconnection between histological indexes was expressed via pair correlation coefficients.

\subsection{Statistical Analysis}

Statistical analysis (calculation of the arithmetical mean, the standard error of the mean and the Student criteria) was performed using standard statistical software ("Excel 2010" «Office XP» and «Statistica 6.0»). The Shapiro-Wilk test was used for testing normality.

\section{Results and Discussion}

The renal capsules of rats from the control group were distinct. Glomerular capillaries were identified clearly in renal corpuscles of renal cortex (Figure 1) Cavity of the capsule of the nephron enlarged moderately. Afferent artery and peritubular capillaries were dilated. Nephrocytes were represented at all levels of renal tubule as prismatic, tubular, cubic or flat shape cells. Tubular epithelial cells had light oxyphilic cytoplasm and basophilic nucleus. 

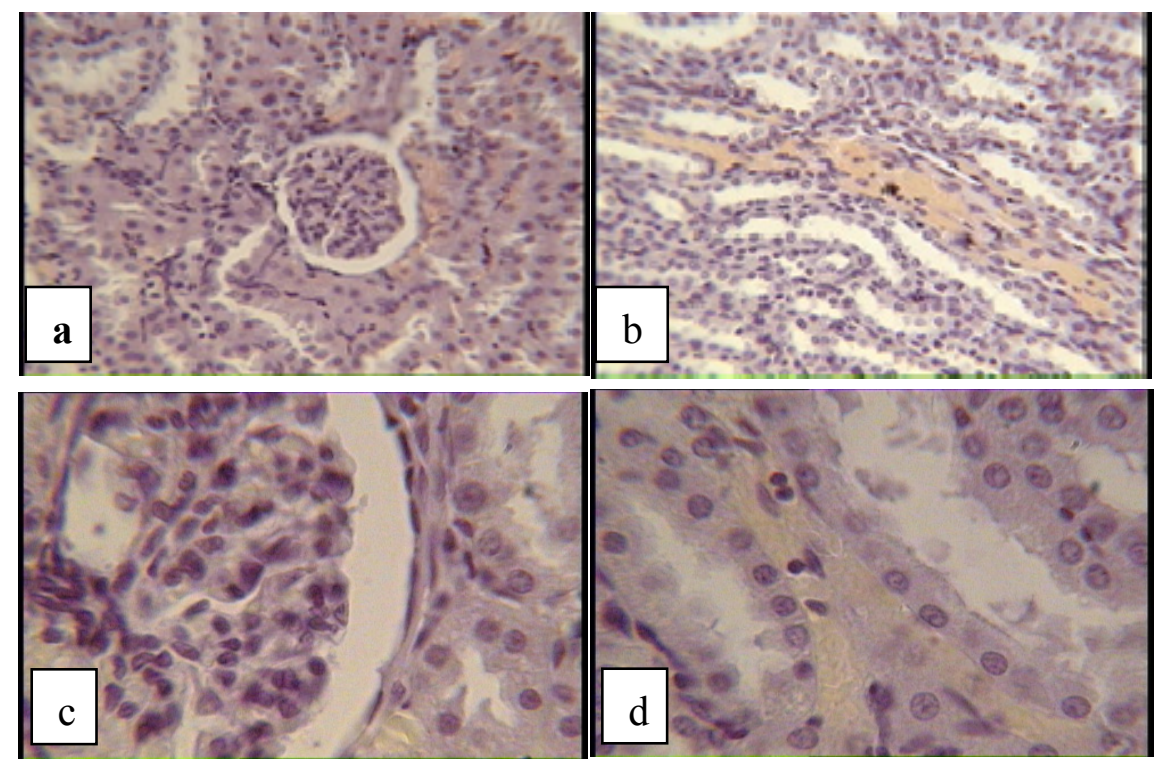

Figure 1. Kidney of a rat from the control group (Routine Mayer's hematoxylin and eosin stain; zoom $\times 600$; 1500)

a - renal corpuscles, renal tubules

$\mathrm{b}$ - renal tubules, radial artery

c - glomerulus, Bowman's capsule

d - renal tubule of distal nephron, capillaries

Experimental rats had a distended and peeled off in some areas renal capsule (Figure 2). There was edema of parenchymatous and stromal elements of renal cortex. The vessels of microvasculature were sludged with erythrocytes. Approximately $65 \%$ of nephrons had destruction and certain microinfarctions. There were polymorphocellular infiltrations around Bowman's capsule, leading to aggravation of destruction in all parts of nephrons. $80 \%$ of glomeruli had reduced volume, but the volume of nephrocytes was extended at all levels of the nephrons. Cavities of renal tubule were extended in the area of Henle's loop. The plasma transudation from extended capillaries to intertubular connective tissue was observed.

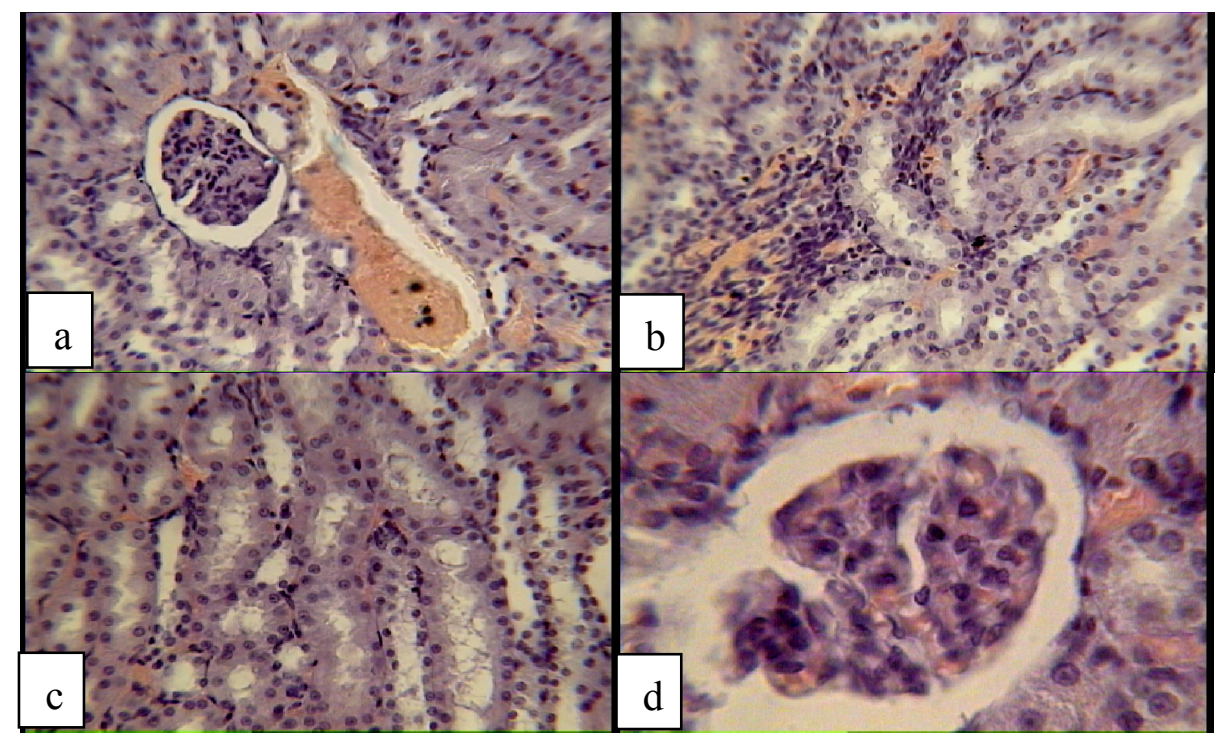

Figure 2. Kidney of a rat from the experimental group (Routine Mayer's hematoxylin and eosin stain; zoom $\times$ $600 ; 1500)$ 
a - renal corpuscles, efferent arteries, peritubular arteries

$\mathrm{b}$ - renal tubules, peritubular vasculature

$\mathrm{c}$ - extended renal tubules

d - renal corpuscle, glomerulus, cavity of Bowman's capsule

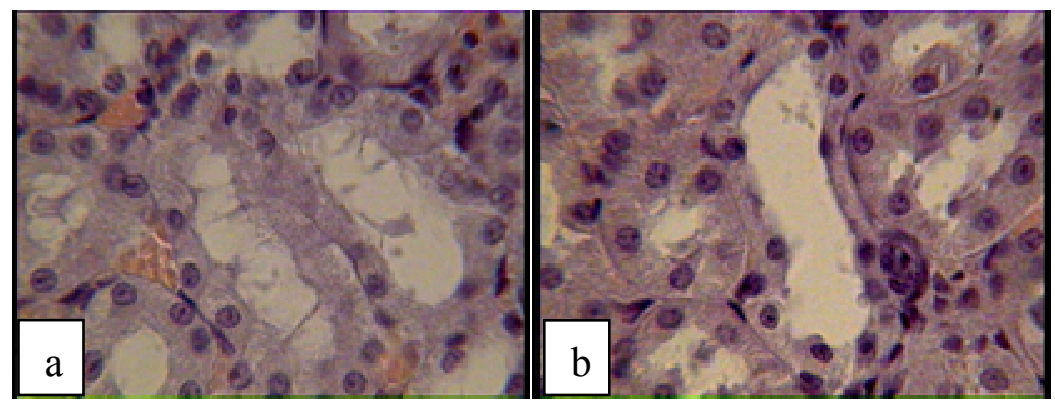

Figure 3. Kidney of a rat from the experimental group (Routine Mayer's and eosin stain; zoom $\times 1500$ ) a - karyolysis and dystrophy of epithelium of extended renal tubules

b - Extended cavity of renal tubule in the area of Henle's loop

After aggregating the morphometrical parameters of the kidneys of rats from the control and experimental groups on the basis of interconnected histological elements we performed the statistical analysis (Table 1).

Table 1. Indicators of histological structure of kidneys of rats in the control and experimental groups, $(\mathrm{M} \pm \mathrm{m})$, $\mathrm{mkm}$

\begin{tabular}{lrr}
\hline & Control group & Experimental group \\
\hline The width of the cavity of the capsule renal corpuscles & $30.29 \pm 1.31$ & $31.69 \pm 7.31$ \\
Diameter of proximal part of nephron tubulus & $39.76 \pm 5.06$ & $37.31 \pm 9.49$ \\
Diameter of descending part of the Henle's loop & $10.34 \pm 0.71^{*}$ & $31.49 \pm 3.13$ \\
Diameter of Capillaries of glomerulus & $33.63 \pm 4.01^{*}$ & $65.23 \pm 6.14$ \\
Diameter of glomerulus & $185.4 \pm 14.59$ & $199.95 \pm 30.37$ \\
Diameter of renal corpuscles & $234.23 \pm 19.1$ & $274.65 \pm 37.27$ \\
Diameter of epithelial cell of proximal part of nephron tubulus & $6.83 \pm 0.83^{*}$ & $8.61 \pm 0.71$ \\
Diameter of nucleus of epithelial cell of proximal part of nephron tubulus & $3.59 \pm 0.35$ & $3.39 \pm 0.15$ \\
\hline
\end{tabular}

Note: statistically significant difference * $(\mathrm{p} \leq 0.05)$.

The relationship between the histological structure of all parts of the kidney of rats in a state of physiological norm ranged from -0.89 to +0.96 . It is mostly positive $(78.6 \%)$ and insignificant $(64.3 \%)$. The relative correlation coefficient was equal to 1.07 , which means that the system was in the state of dynamic equilibrium.

The correlation was significant between the volume of the nucleus of epithelial cells of the proximal part of nephron and: the volume of the proximal part of nephron epithelial cells $(r=0.96)$; the diameter of microvessels of glomerulus $(\mathrm{r}=0.95)$; the diameter of the proximal part of the nephron $(\mathrm{r}=0.77)$.

The correlation was significant between the volume of the proximal part of nephron epithelial cells and: the diameter of the proximal part of the nephron $(r=0.92)$; the diameter of microvessels of glomerulus $(r=0.88)$; the volume of glomerulus $(r=0.78)$. The correlation was significant between renal corpuscles volume and: the diameter of the nephron in the Henle's loop area $(r=0.91)$; the volume of the cavity of the Bowman's capsule $(r$ $=0.82)$; the diameter of microvessels of glomerulus $(\mathrm{r}=0.79)$.

Thus, the leading structures in the kidney of rats from the control group are: the volume of the nuclei of epithelial cells and of the epithelial cells of the proximal part of nephron themselves, and the volume of renal cells that exhibit a high degree of correlation with the diameters of microvessels of glomerulus, channel of the nephron and volume of the cavity of the Bowman's capsule.

In the kidney of rats from the experimental group the correlation between the histological structure of all parts of 
the kidney ranged from -0.79 to +0.96 . It is positive $(64.3 \%)$ and mostly insignificant $(82.1 \%)$.

The relative correlation coefficient was 1.2 , which means that the system was implementing a set of adaptive reactions to maintain its dynamic equilibrium. In comparison with the state of the kidney of rats from the control group the complex implemented adaptive reactions expressed in the change of leading structures. The correlation was significant between the volume of glomerulus and: the volume of the cavity of the Bowman's capsule $(\mathrm{r}=$ $0.86)$; the diameters of microvessels of glomerulus $(r=-0.79)$; the diameter of the proximal part of the nephron $(\mathrm{r}=0.77)$. The correlation was significant between renal corpuscle volume and the diameter of the proximal part of the nephron $(\mathrm{r}=0.96)$.

The correlation was significant between the epithelial cells of the proximal volume of the nephron and the volume of the cavity of the Bowman's capsule $(\mathrm{r}=0.82)$.

The elemental homeostasis was evaluated with the use of the blood and hair of laboratory animals as biosubstrates. The study showed the development of diselementosis under the influence of intoxication, which expressed in a decrease concentration of $\mathrm{Mg}, \mathrm{P}, \mathrm{As}, \mathrm{Fe}, \mathrm{Cu}, \mathrm{Si}, \mathrm{Zn}$ in the blood, and increase concentration of $\mathrm{Cd}$ (Table 2).

Table 2. Averages content of the chemical elements in the blood of laboratory animals $(\mathrm{M} \pm \mathrm{m}), \mathrm{mg} / \mathrm{kg}$

\begin{tabular}{ccc}
\hline Element & Experimental group & Control group \\
\hline $\mathrm{Mg}$ & $47.4 \pm 1.98$ & $50.3 \pm 1.62$ \\
$\mathrm{P}$ & $412 \pm 5^{*}$ & $498 \pm 25$ \\
$\mathrm{As}$ & $0.54 \pm 0.1^{* *}$ & $1.05 \pm 0.04$ \\
$\mathrm{Cu}$ & $0.98 \pm 0.08$ & $1.05 \pm 0.02$ \\
$\mathrm{Fe}$ & $359 \pm 31^{*}$ & $539 \pm 14$ \\
$\mathrm{Si}$ & $0.5 \pm 0.13^{* *}$ & $2.5 \pm 0.5$ \\
$\mathrm{Zn}$ & $5.6 \pm 0.1^{*}$ & $6.4 \pm 0.3$ \\
$\mathrm{Cd}$ & $0.03 \pm 0.004^{* * *}$ & $0.0002 \pm 0.00007$ \\
\hline
\end{tabular}

Note: The symbol * denotes a significant difference between the experimental group and the control group $(\mathrm{p} \leq$ $0.05) ; \quad * *(\mathrm{p} \leq 0.01) ; \quad * * *(\mathrm{p} \leq 0.001)$.

Our results are consistent with those of other authors. It is known that a deficiency of phosphorus may occur during intoxication with ethanol. A number of authors (Rebrov \& Gromova, 2008) point out that alcohol increases the loss of magnesium through the kidneys and alcoholics are often found deficient in this element. The effect of ethanol on the increase in nephrotoxicity of cadmium in rats was proposed in the work (Brzoska, Moniuszko-Jakoniuk, Piłat-Marcinkiewicz, \& Sawicki, 2003). Clinical studies confirm the toxic effects of cadmium on renal function (de Burbure, C. et al., 2006). Thus, it can be assumed that people who abuse alcohol are at greater risk of kidney damage when exposed to cadmium. The content of iron, zinc and copper were lower in the blood of animals from the test group. Low iron concentration may be a result of its intense consumption by hepatocytes during chronic intoxication with ethanol, which may be due to the increased number of ferritin receptors (Jurczuk, M., Brzóska, M. M., Rogalska, J., \& Moniuszko-Jakoniuk, J., 2003). Low levels of zinc is apparently a consequence of the high content of lead and cadmium, which are antagonists.

The results of studying of the elemental composition of rats' hair are presented in the Table 3.

Table 3. Average content of chemical elements in the hair of laboratory animals $(M \pm m), \mathrm{mg} / \mathrm{kg}$

\begin{tabular}{ccc}
\hline Element & Experimental group & Control group \\
\hline $\mathrm{K}$ & $2233 \pm 85^{*}$ & $1713 \pm 42$ \\
$\mathrm{As}$ & $0.03 \pm 0.003^{* *}$ & $0.07 \pm 0.009$ \\
$\mathrm{Co}$ & $0.005 \pm 0.0004^{*}$ & $0.009 \pm 0.0004$ \\
$\mathrm{Cr}$ & $0.35 \pm 0.04^{*}$ & $0.59 \pm 0.06$ \\
$\mathrm{Fe}$ & $9.5 \pm 0.5^{* *}$ & $14.7 \pm 1.3$ \\
$\mathrm{Ni}$ & $0.12 \pm 0.01^{*}$ & $0.18 \pm 0.01$ \\
$\mathrm{Zn}$ & $191 \pm 17^{*}$ & $146 \pm 4$ \\
$\mathrm{Cd}$ & $6.06 \pm 0.93^{* * *}$ & $0.07 \pm 0.01$ \\
$\mathrm{~Pb}$ & $0.002 \pm 0.001^{*}$ & $0.05 \pm 0.02$ \\
\hline
\end{tabular}

Note: The symbol * denotes a significant difference between the experimental group and the control group $(\mathrm{p} \leq$ $0.05) ; \quad * *(\mathrm{r} \leq 0.01) ; * * *(\mathrm{r} \leq 0.001)$. 
Among the macroelements it was only potassium which concentration in rats' hair significantly differed between the control and the experimental groups. Its concentration in the hair of rats from the control group was increased by $30 \%$ in comparison with the experimental. Among the essential and conditionally essential elements, the concentrations of arsenic, cobalt, chromium, iron, nickel and zinc were significantly different between the groups.

The concentration of all these elements except for zinc was lower in the hair of animals from the experimental group: arsenic was decreased by 2.3 times compared to control $(\mathrm{p} \leq 0,01)$, cobalt was decreased by 1.8 times ( $p$ $\leq 0.05)$, chromium was decreased by 1.7 times $(p \leq 0,05)$, iron $(p \leq 0,01)$ and nickel $(p \leq 0.05)$ were decreased by 1.5 times, zinc was increased by 1.5 times. There were no significant differences among the concentrations of other elements in the two groups. The significant differences in the content of the toxic and potentially toxic elements were obtained for cadmium and lead. The concentration of cadmium was 86 times $(p \leq 0,001)$ higher and the concentration of lead was 25 times $(\mathrm{p} \leq 0.05)$ higher in the hair of animals from the experimental group than in the hair of animals from the control group.

The administration of alcohol orally at a dose of ( $2 \mathrm{~g} / \mathrm{kg}$ body weight orally for 30 days $)$ resulted severe congestion of renal blood vessels, necrosis of the renal cell, severe degenerative changes in tubules and damaged glomeruli (Shanmugam, K. R., Ramakrishna, C. H., Mallikarjuna, K., \& Reddy, K. S., 2010). Chronic ethanol administration (3 g/kg b.w) during 12 weeks to Wistar rats lead to renal dysfunction (Alimi, H., Bouoni, Z., Feriani, A., Hfaeidh, N., Sakly, M., \& Tunisia, K. B., 2013). The rats treated with Cd (3 mg Cd/kg b.w.) had histopathological changes: shrinking or degeneration of the glomerular tuft, cytoplasmic degeneration of cells of the renal tubules, multiple foci of haemorrhage, dilatation and congestion of blood vessels (El-Refaiy, A. I., \& Eissa, F. I., 2013).

In this study we examined the changes in renal tissue during simultaneous exposure to multiple toxicants (ethanol and cadmium) on the body of laboratory animals. Taking into consideration the abundance of drinking alcohol and tobacco smoking among the population of the Russian Federation, the combined effect of the two substances is not uncommon (Onishchenko, 2003). Our results indicate the presence of clearly distinguishable morphological and functional changes in the kidney of rats under effect of ethanol and cadmium. Since ethanol increases the permeability of biological membranes for cadmium (Pal, Nath, \& Gill, 1993) people who use alcohol are more susceptible to the effects of this heavy metal.

\section{Conclusion}

It was revealed that the rats of the experimental group had about $65 \%$ of nephrons exposed to destruction with microinfarctions, $80 \%$ of kidney cells reduced their volume, while at all levels of the nephron the neprocytes had an increased volume. The volumes of glomerulus and renal corpuscles were the leading structures in the kidney of animals of the experimental group, the volume of the proximal part of nephron epithelial cells showed correlation only with the volume of the cavity of the Bowmans' capsule, indicating the desynchronization of correlation structures of the system (in comparison with the control group), expressed in the kidney failure. The investigated content of chemical elements in the blood of laboratory animals indicates the development of changes of the element status under the influence of the consumption of ethanol in combination with cadmium.

\section{Acknowledgement}

The research is carried out through the grant of the Russian Science Foundation (project \#14-16-00060).

\section{References}

Aghajanian, N. A., \& Skalny, A. V. (2001). Himicheskie elementy v srede obitanija i ekologicheskij portret cheloveka. Chemical elements in the environment and ecological portrait of a man. Moscow, Moscow: Publishing House of the KMK.

Alimi, H., Bouoni, Z., Feriani, A., Hfaeidh, N., Sakly, M., \& Tunisia, K. B. (2013). Opuntia ficus indica f. inermis fruit juice alleviates ethanol-induced kidney injury in rats. Asian Journal of Biomedical and Pharmaceutical Sciences, 3(19), 15-21. http://dx.doi.org/10.15272/ajbps.v3i19.238

Brzoska, M. M., Moniuszko-Jakoniuk, J., Piłat-Marcinkiewicz, B., \& Sawicki, B. (2003). Liver and kidney function and histology in rats exposed to cadmium and ethanol. Alcohol and Alcoholism, 38(1), 2-10. http://dx.doi.org/10.1093/alcalc/agg006

Buchet, J. P., de Burbure, C., Leroyer, A., Nisse, C., Haguenoer, J. M., Mutti, A., ... \& Bernard, A. (2006). Renal and neurologic effects of cadmium, lead, mercury, and arsenic in children: evidence of early effects and multiple interactions at environmental exposure levels. Environmental Health Perspectives, 584-590. 
http://dx.doi.org/10.1289/ehp.8202

El-Refaiy, A. I., \& Eissa, F. I. (2013). Histopathology and cytotoxicity as biomarkers in treated rats with cadmium and some therapeutic agents. Saudi journal of biological sciences, 20(3), 265-280. http://dx.doi.org/10.1016/j.sjbs.2013.02.004

Ergen, K., Yildiz, F., Ozcan, M., Çekmen, M., Tanyeri, P., Utkan, T., \& Karakoç, Y. (2012). Effects of cigarette smoke on tissue trace element concentration of rats exposed to second-hand smoke. Medicine Science, 1(1).

Falcon, M., Vinas, P., Perez-Carceles, M. D., \& Luna, A. (2003). Placental cadmium and lipid peroxidation in smoking women related to newborn anthropometric measurements. Archives of Environmental Contamination and Toxicology, 45(2), 278-282.

Gerke, P., Hapke, U., Rumpf, H. J., \& John, U. (1997). Alcohol-related diseases in general hospital patients. Alcohol and Alcoholism, 32(2), 179-184. http://dx.doi.org/10.1093/oxfordjournals.alcalc.a008252

Ikeda, M., Zhang, Z. W., Moon, C. S., Shimbo, S., Watanabe, T., Nakatsuka, H., ... \& Higashikawa, K. (2000). Normal liver function in women in the general Japanese population subjected to environmental exposure to cadmium at various levels. International Archives of Occupational and Environmental Health, 73(2), 86-90. http://dx.doi.org/10.1007/PL00007943

Izmerov, N. F. (1984). Mezhdunarodnyj registr potencial'no toksichnyh himicheskih veshhestv. Kadmij. T. № 69. International Register of Potentially Toxic Chemicals. Cadmium. V. 69. Center for International Projects SCCT, MA.

Jurczuk, M., Brzóska, M. M., Rogalska, J., \& Moniuszko-Jakoniuk, J. (2003). Iron body status of rats chronically exposed to cadmium and ethanol. Alcohol and Alcoholism, 38(3), 202-207. http://dx.doi.org/10.1093/alcalc/agg057

Lyon, T. D., Patriarca, M., Howatson, A. G., Fleming, P. J., Blair, P. S., \& Fell, G. S. (2002). Age dependence of potentially toxic elements $(\mathrm{Sb}, \mathrm{Cd}, \mathrm{Pb}, \mathrm{Ag})$ in human liver tissue from paediatric subjects. Journal of Environmental Monitoring, 4(6), 1034-1039. http://dx.doi.org/10.1039/b205972j

Malov, A. M., Sibiryakov, V. C., \& Ivanenko, A. A. (2013) Accumulation of cadmium in some organs and tissues of rats. Clinical toxicology, 14, 228-240.

McIntosh, C., \& Chick, J. (2004). Alcohol and the nervous system. Journal of Neurology, Neurosurgery \& Psychiatry, 75(suppl 3), 16-21. http://dx.doi.org/10.1136/jnnp.2004.045708

Moniuszko-Jakoniuk, J., Galazyn-Sidorczuk, M., Brzóska, M. M., Jurczuk, M., \& Kowalczyk, M. (2001). Effect of short-term ethanol administration on cadmium excretion in rats. Bulletin of Environmental Contamination and Toxicology, 66(1), 125-131. http://dx.doi.org/10.1007/s001280000214

Onishchenko, G. G. (2003). Okruzhajushhaja sreda i sostojanie zdorov'ja naselenija RF Environment and health of the population of the Russian Federation. Health of the Russian Federation, 5, 8-11.

Pal, R., Nath, R., \& Gill, K. D. (1993). Influence of ethanol on cadmium accumulation and its impact on lipid peroxidation and membrane bound functional enzymes $(\mathrm{Na}+, \mathrm{K}+$-ATPase and acetylcholinesterase) in various regions of adult rat brain. Neurochemistry International, 23(5), 451-458. http://dx.doi.org/10.1016/0197-0186(93)90129-S

Rebrov, V. G., \& Gromova, O. A. (2008). Vitaminy, makro- i mikrojelementy. Obuchajushhie programmy RSC instituta mikrojelementov JuNESKO [Vitamins, macro- and microelements. Tutorials of the RIC Institute of trace elements of the UNESCO Moscow, M.: GEOTAR Media.

Shanmugam, K. R., Ramakrishna, C. H., Mallikarjuna, K., \& Reddy, K. S. (2010). Protective effect of ginger against alcohol-induced renal damage and antioxidant enzymes in male albino rats.

Stepanova, N. V. (2003). Ranzhirovanie gorodskoj territorii po urovnju zagrjaznenija tjazhelymi metallami. Ranking urban area on the level of contamination by heavy metals. Bul. ESSC SB RAMS, 2, 75-77.

\section{Copyrights}

Copyright for this article is retained by the author(s), with first publication rights granted to the journal.

This is an open-access article distributed under the terms and conditions of the Creative Commons Attribution license (http://creativecommons.org/licenses/by/3.0/). 